\title{
Occurrence and Geographical Distribution of Tospovirus Species Infecting Tomato Crops in Argentina
}

\begin{abstract}
L. V. Williams, Secretaría de Ciencia y Tecnología de la Universidad Nacional de Córdoba (SECyT)-Instituto de Fitopatología y Fisiología Vegetal (IFFIVE-INTA), Camino 60 Cuadras Km $5^{1 / 2}$ (5119) Córdoba, Argentina; P. M. López Lambertini, Instituto de Fitopatología y Fisiología Vegetal (IFFIVE-INTA), Camino 60 Cuadras Km 5 $5^{1 / 2}$ (5119) Córdoba, Argentina; K. Shohara, Expert from the Japanese International Cooperation Agency (JICA). Japan; and E. B. Biderbost, Instituto de Fitopatología y Fisiología Vegetal (IFFIVE-INTA). Camino 60 Cuadras Km $5^{1 / 2}$ (5119) Córdoba, Argentina
\end{abstract}

\begin{abstract}
Williams, L. V., López Lambertini, P. M., Shohara, K., and Biderbost, E. B. 2001. Occurrence and geographical distribution of tospovirus species infecting tomato crops in Argentina. Plant Dis. 85:1227-1229.

"Peste negra" is a disease, caused by tospoviruses, that affects tomato crops in Argentina. Knowledge of the diversity, frequency, and distribution of different tospoviruses is essential for developing a rational control program based on genetic resistance sources. A study of the geographical distribution of tospoviruses affecting tomato crops in Argentina is presented in this paper. The areas surveyed were between the Tropic of Capricorn and $40^{\circ} \mathrm{S}$ and between longitude $58^{\circ} \mathrm{W}$ and $70^{\circ} \mathrm{W}$. Tospovirus species were identified through double-antibody sandwich enzyme-linked immunosorbent assay (DAS-ELISA), using polyclonal antisera against Tomato spotted wilt virus (TSWV), Groundnut ringspot virus (GRSV), and Tomato chlorotic spot virus (TCSV). From tomato samples that reacted positively with any of the used antisera, 63\% were GRSV, $28.2 \%$ were TCSV, and $8.8 \%$ were TSWV. A differential geographical distribution of tospoviruses was determined. Every plant that tested positive for GRSV was from central and northwest Argentina, while every plant TCSV-positive was from the northeast. TSWV was found only in the Río Negro Valley region in the south of the country. The wide dispersion of GRSV may be related to the spread of Frankliniella shultzei, which transmits this virus more efficiently than other vectors.
\end{abstract}

Additional keywords: Lycopersicon esculentum Mill.

\begin{abstract}
"Peste negra" is one of the main viral diseases affecting tomato (Lycopersicon esculentum Mill.) in Argentina. It is caused by different species of the genus Tospovirus, family Bunyaviridae (8), which are transmitted by thrips (Thysanoptera) (9). First noticed in tomato crops in 1938 (7), tospoviruses presently affect many economically important crops such as tomato, lettuce (Lactuca sativa L.), pepper (Capsicum annuum L.), and tobacco (Nicotiana tabacum L.), and they are increasing their incidence in ornamentals.
\end{abstract}

Corresponding author: E. B. Biderbost

E-mail: biderbos@onenet.com.ar

This study was financed by Instituto Nacional de Tecnología Agropecuaria (INTA), Consejo de Investigaciones de Córdoba (CONICOR) and the Japanese International Cooperation Agency (JICA).

Accepted for publication 13 July 2001.

Publication no. D-2001-0925-01R

(C) 2001 The American Phytopathological Society
The significance of the losses caused by tospoviruses in Argentina is variable but has been up to $80 \%$ (E. Biderbost, unpublished). Yield loss estimates on susceptible tomato cultivars indicated up to $54 \%$ fewer fruit and $65 \%$ less fruit weight than in the same noninfected cultivars (2).

Tospoviruses are widespread and have great diversity in South America. In Brazil, seven species of tospoviruses have been detected: Tomato spotted wilt virus (TSWV), Groundnut ringspot virus (GRSV), Tomato chlorotic spot virus (TCSV), Impatiens necrotic spot virus (INSV), Iris yellow spot virus (IYSV) $(12,14)$, Zucchini lethal chlorotic spot virus (ZLCV), and Chrysanthemum stem necrosis virus (CSNV) (1). The tospoviruses infecting tomato in Brazil include TSWV, GRSV, TCSV, and CSNV. Both, Frankliniella occidentalis Pergande and $F$. shultzei Trybom have been reported as vectors of tospoviruses in tomato (11).

In Argentina, TSWV, GRSV, and TCSV have been identified (6). Disease management in tomato is based on eradication of infected plants and use of insecticides to control vectors. An integrated management program for "peste negra" that includes resistant tomato cultivars requires information about diversity, frequency, and distribution of tospovirus species and their vectors. Here we report on the occurrence and distribution of tospovirus species in the main tomato producing-region of Argentina.

\section{MATERIALS AND METHODS}

Survey. Samples were collected from different horticultural regions between the Tropic of Capricorn and $40^{\circ} \mathrm{S}$ and between longitude $58^{\circ} \mathrm{W}$ and $70^{\circ} \mathrm{W}$. The tomato producing areas included were the northwest (provinces of Salta, Jujuy, and Tucumán), the center (province of Córdoba), the northeast and Littoral (provinces of Corrientes, Santa Fé, and Buenos Aires), and the Rio Negro Valley (province of Río Negro). Surveys were performed from June 1996 to August 1997, depending on the tomato-producing period in each region. Apical leaves of plants showing typical tospovirus symptoms (bronzing, distortion, mosaic, and ring spots) were collected. Tomato plants (420 samples) were collected from the following cultivars: Gaucho, Diva, Pitihue-INTA, UcoPlata, Platense, Rio Grande, Oso, Santa Clara, Lider, Presto, Tommy, Carmelo, Lucia, UCO 5, Platense italiano, Pomarola, and BHN-81. During collection, samples were cooled on ice in the field and then stored at $-80^{\circ} \mathrm{C}$ until the double-antibody sandwich enzyme-linked immunosorbent assays (DAS-ELISA) were performed.

Identification of tospovirus species. TSWV, GRSV, and TCSV were identified by DAS-ELISA using the procedure as described by Clark and Adams (3) with an additional step of blocking (4\% nonfat milk in carbonate buffer, $\mathrm{pH}$ 9.6). Polyclonal antiserum against the nucleocapsid proteins of GRSV, TCSV, and TSWV were used. The samples, apical symptomatic leaves, were ground in a ratio 1:10 (wt/vol) in extraction buffer (phosphate-buffered saline, $0.05 \%$ Tween $20,2 \%$ polyvinylpyrrolidone, $0.01 \mathrm{M}$ sodium sulfite). 
Table 1. Design of the double-antibody sandwich enzyme-linked immunosorbent assay (DAS-ELISA) microtiter plates for the identification of tospovirus species $^{\mathrm{a}}$

\begin{tabular}{|c|c|c|c|c|c|c|c|c|}
\hline \multicolumn{3}{|c|}{ IgG and enzymatic conjugate anti-TSWV } & \multicolumn{3}{|c|}{ IgG and enzymatic conjugate anti-GRSV } & \multicolumn{3}{|c|}{ IgG and enzymatic conjugate anti-TCSV } \\
\hline $\begin{array}{l}\text { Healthy con- } \\
\text { trol } \mathrm{T}^{\mathrm{b}}\end{array}$ & $\begin{array}{l}\text { Healthy con- } \\
\text { trol } \mathrm{T}\end{array}$ & $\begin{array}{l}\text { Healthy con- } \\
\text { trol N }\end{array}$ & $\begin{array}{l}\text { Healthy con- } \\
\text { trol T }\end{array}$ & $\begin{array}{l}\text { Healthy con- } \\
\text { trol T }\end{array}$ & $\begin{array}{l}\text { Healthy con- } \\
\text { trol N }\end{array}$ & $\begin{array}{l}\text { Healthy con- } \\
\text { trol T }\end{array}$ & $\begin{array}{l}\text { Healthy con- } \\
\text { trol T }\end{array}$ & $\begin{array}{l}\text { Healthy con- } \\
\text { trol N }\end{array}$ \\
\hline $\begin{array}{l}\text { TSWV in- } \\
\text { fected control }\end{array}$ & $\begin{array}{c}\text { GRSV in- } \\
\text { fected control }\end{array}$ & $\begin{array}{c}\text { TCSV in- } \\
\text { fected control }\end{array}$ & $\begin{array}{l}\text { TSWV in- } \\
\text { fected control }\end{array}$ & $\begin{array}{c}\text { GRSV in- } \\
\text { fected control }\end{array}$ & $\begin{array}{c}\text { TCSV in- } \\
\text { fected control }\end{array}$ & $\begin{array}{l}\text { TSWV in- } \\
\text { fected control }\end{array}$ & $\begin{array}{l}\text { GRSV in- } \\
\text { fected control }\end{array}$ & $\begin{array}{c}\text { TCSV in- } \\
\text { fected control }\end{array}$ \\
\hline Sample $1^{\mathrm{c}}$ & Sample 2 & Sample 3 & Sample 1 & Sample 2 & Sample 3 & Sample 1 & Sample 2 & Sample 3 \\
\hline
\end{tabular}

a Tomato spotted wilt virus (TSWV), Groundnut ringspot virus (GRSV), and Tomato chlorotic spot virus (TCSV).

b Healthy control: T (tomato), N (Nicotiana rustica).

c Samples 1, 2, and 3: extracts from field tomato plants with symptoms of tospoviruses.

Because polyclonal antisera to TSWV, GRSV, and TCSV have some degree of cross-reaction, the optimal dilution combinations of immunoglobulin (IgG) and enzymatic conjugate were calibrated to achieve the highest reaction with the homologous antigen, the minimum crossreaction with the heterologous species, and no reaction with healthy plants. The dilution of anti-GRSV, anti-TCSV, and antiTSWV IgG were 1:1,000 ( $\mathrm{vol} / \mathrm{vol})$, and the enzymatic conjugate dilutions were $1: 1,500(\mathrm{vol} / \mathrm{vol}), 1: 2,000(\mathrm{vol} / \mathrm{vol})$, and $1: 2,500$ ( $\mathrm{vol} / \mathrm{vol})$, respectively. The assay was run so that both homologous and heterologous reactions could be compared in each plate (Table 1). Extracts from Nicotiana rustica infected with TSWV, GRSV, or TCSV were used as positive controls, and extracts from healthy tomato and $N$. rustica were used as negative controls. Each sample and each control was assayed in the same plate with all three antisera (anti-GRSV, anti-TSWV, and anti-TCSV). The serum that gave the highest absorbance value could then determine the identity of the tospovirus species present in each sample. Homologous, heterologous, and negative controls for each of the antisera provided reference absorbance values that allow us to discount any crossreaction. DAS-ELISA absorbance values at $405 \mathrm{~nm}$ were recorded by an MR 4000 plate reader (Dynatech Laboratories, Inc., Chantilly, VA). Samples were considered positive when their absorbance values were greater than three times the mean of the healthy extract absorbance values.

\section{RESULTS}

Identification of tospoviruses. The procedure for DAS-ELISA calibration here proposed allowed the identification of TSWV, TCSV, and GRSV with confidence and high sensitivity even in plants with low virus concentration (Fig. 1).

Occurrence and distribution of tospoviruses. The occurrence of TSWV, GRSV, and TCSV was confirmed in tomato. Results of the survey are summarized in Table 2 and Figure 2. Of the 420 samples assayed, 170 showed positive reaction in DAS-ELISA; 63\% were identified as GRSV, $28.2 \%$ as TCSV, and $8.8 \%$ as TSWV. These results indicate that GRSV was the predominant species

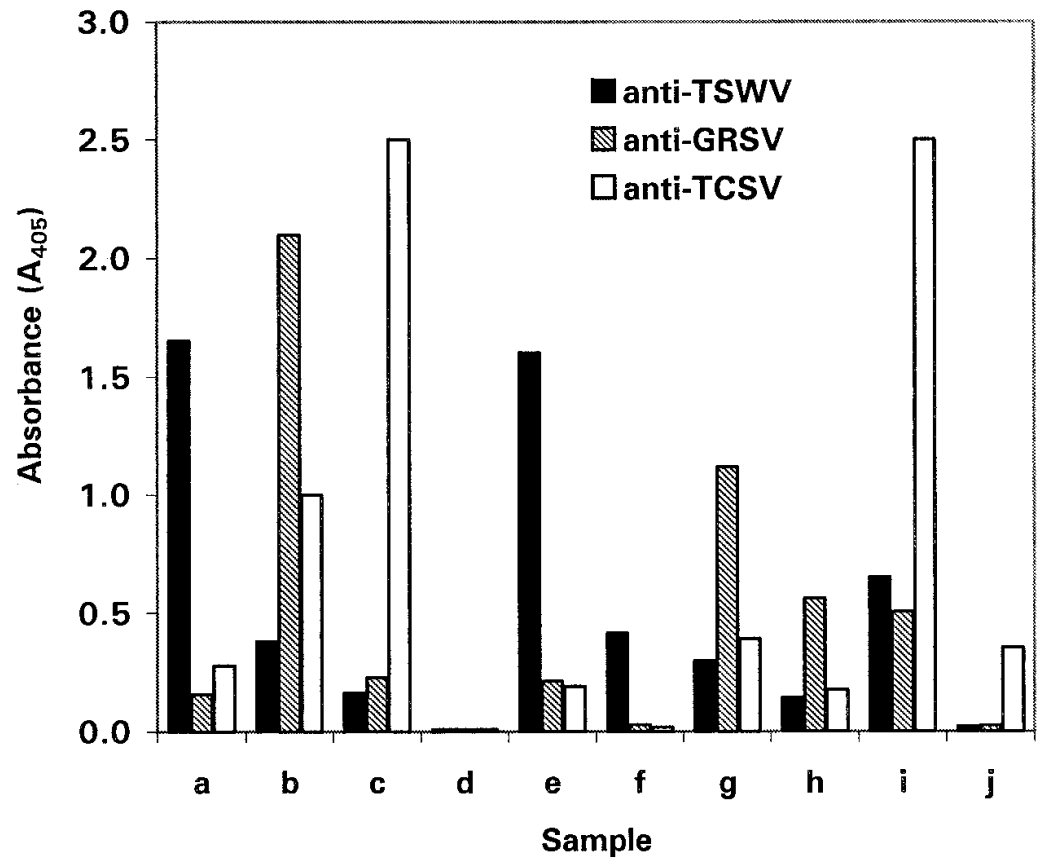

Fig. 1. Standard double-antibody sandwich enzyme-linked immunosorbent assay (DAS-ELISA) absorbance values using the optimized procedure for identification of Tomato spotted wilt virus (TSWV), Groundnut ringspot virus (GRSV), and Tomato chlorotic spot virus (TCSV). a, b, and c: control reactions for TSWV, GRSV, TCSV, respectively; d: healthy control reaction; e, g, and i: tomato samples with high viral concentration; $\mathrm{f}, \mathrm{h}$, and $\mathrm{j}$ : tomato samples with low viral concentration.

detected in the survey. Every plant positive for GRSV was from the central and northwest region, while every plant TCSV-positive was from the northeast and littoral region. TSWV was only found in the Río Negro Valley region (Fig. 2). These findings indicate a particular geographical distribution of the different species of tospoviruses in tomato in Argentina.

Mixed infections of GRSV, TCSV, and TSWV were not found since none of the samples assayed produced equivalently positive reactions with more than one of the antisera used.

A significant number of plants (Table 2) did not react serologically with any of the antisera used, although they presented symptoms that could be attributed to tospovirus infection.

No correlation between symptom and tospovirus species could be determined. However, most of the plants infected with TCSV showed severe necrosis of the apical leaves as their main symptom.

\section{DISCUSSION}

The effectiveness of the DAS-ELISA procedure described here can be visualized if one considers that although the amino acid sequences of the nucleocapsid proteins of TSWV, GRSV, and TCSV share high percentages of homology (77 to $81 \%$ ), the species could be differentiated (4). The negative results in DAS-ELISA for samples that showed typical tospovirus symptomatology could be due to low viral concentration in the samples assayed or perhaps to new tospovirus species.

We found that GRSV was the most widespread tospovirus species and could therefore have the highest economic impact on tomato in Argentina. In agreement with our results, Gracia et al. (10) reported the prevalence of GRSV in the Andean horticultural region situated in western Argentina. In Brazil, GRSV is also the predominant species infecting tomato crops (1).

The particular geographical distribution of the different tospovirus species detected in tomato crops in Argentina is an interest- 
Table 2. Occurrence of tospoviruses on tomato crops collected from different tomato-producing regions

\begin{tabular}{|c|c|c|c|c|}
\hline \multirow[b]{2}{*}{ Region/location } & \multirow[b]{2}{*}{ Plants sampled } & \multicolumn{3}{|c|}{ DAS-ELISA $^{a}$} \\
\hline & & GRSV & TCSV & TSWV \\
\hline \multicolumn{5}{|l|}{ Northwest } \\
\hline Palma Sola (Jujuy) & 30 & 9 & 0 & 0 \\
\hline Orán (Salta) & 32 & 1 & 0 & 0 \\
\hline San Miguel (Tucumán) & 44 & 26 & 0 & 0 \\
\hline \multicolumn{5}{|l|}{ Central } \\
\hline V. Dolores (Córdoba) & 100 & 39 & 0 & 0 \\
\hline Cruz del Eje (Córdoba) & 112 & 32 & 0 & 0 \\
\hline \multicolumn{5}{|l|}{ Northeast and littoral } \\
\hline B. Vista (Corrientes) & 10 & 0 & 4 & 0 \\
\hline Esperanza (Santa Fé) & 41 & 0 & 30 & 0 \\
\hline Rosario (Santa Fé) & 10 & 0 & 8 & 0 \\
\hline San Pedro (Bs. As.) & 14 & 0 & 6 & 0 \\
\hline \multicolumn{5}{|l|}{ Río Negro Valley } \\
\hline General Roca & 12 & 0 & 0 & 9 \\
\hline Alto Valle & 15 & 0 & 0 & 6 \\
\hline Total & 420 & 107 & 48 & 15 \\
\hline
\end{tabular}

${ }^{a}$ Number of samples that reacted with each tested antisera by double-antibody sandwich enzymelinked immunosorbent assay. Groundnut ringspot virus (GRSV), Tomato chlorotic spot virus (TCSV), and Tomato spotted wilt virus (TSWV).

ing phenomenon. The almost exclusive presence of one virus species in each geographic area might be attributed to vector competition and efficiency of transmission of each virus species. Propagative viruses like tospoviruses are circulative and replicate in their insect vectors as well as in host plants, and their relationships with vectors are highly specific (13). In Argentina, the wide dispersion of tospoviruses can be attributed to $F$. occidentalis and $F$. shultzei, the only two species of thrips identified as transmitters (5). Studies performed by Nagata et al. (11) indicated that $F$. occidentalis might transmit TSWV more efficiently than GRSV and TCSV, while $F$. shultzei is a more efficient vector for GRSV. Furthermore, F. shultzei transmits TCSV but not TSWV. Recent surveys of thrips in the northern and central areas of Argentina showed the presence of $F$. shultzei (A. Kawai, personal communication) in the same areas where GRSV was prevalent.

Although plants that serve as reservoirs for tospoviruses may play an important role in virus geographical distribution, this is not the case for TSWV, which has a very broad host range and was restricted to the Rio Negro Valley in our survey. On the other hand, GRSV has a narrow host range (only tomato and lettuce have been reported as its hosts in Argentina) and a broad distribution (10). This seems to indicate that efficiency of $F$. shultzei in transmitting GRSV is the determining factor for its dispersion.

The lack of information on distribution and transmission efficiency of the vectors in Argentina makes it difficult to know the correlation between thrips and TCSV or TSWV. New tospovirus species are identified faster than their vectors. Therefore, knowledge of tospovirus disease epidemiology grows slowly. More epidemiological studies are needed to determine these relationships in the future.

The great variety of tospovirus species found in Brazil encourages continuing the survey with antisera against other serogroups.

\section{ACKNOWLEDGMENTS}

We thank J. C. Favaro (Universidad Nacional de Santa Fé), V. Mollinedo (INTA-Yuto, Jujuy), J. C. Ramallo (Universidad Nacional de Tucumán), E. Orechia (INTA-AER Cruz del Eje, Córdoba), E. Alvarez (Universidad Nacional del Litoral), M. Colombo (INTA-EEA Bella Vista, Corrientes), I. Mitidieri (INTA-EEA San Pedro, Buenos Aires), D. Calvar (INTA-EEA Alto Valle, Río Negro), and C. Mondino (INTA-AER Arroyo Seco) for the valuable collaboration in collecting samples. We also thank Antonio Carlos de Ávila (EMBRAPA, Brasil) for kindly providing antisera against TCSV and Daniel Ducasse (IFFIVE-INTA, Argentina) for valuable suggestions and review of the manuscript.

\section{LITERATURE CITED}

1. Bezerra, I. C., Resende, R. de O., Pozzer, L., Nagata, T., Kormelink, R., and De Avila, A. C. 1999. Increase of tospoviral diversity in Brazil with the identification of two new tospovirus species, one from chrysanthemum and one from zucchini. Phytopathology 89:823-830.

2. Biderbost, E. B., Nome, S. F., and Mollinedo, V. A. 1989. Estimación de daños producidos por el virus de la Peste Negra (TSWV) en diez variedades de tomate para industria (Lycopersicon esculentum Mill.). Page 66 in: VII Jornadas Fitosanitarias Argentinas, Salta, Argentina.

3. Clark, M. F., and Adams, A. N. 1977. Characteristics of microplate methods of enzyme immunosorbent assay for the detection of plant virus. J. Gen. Virol. 34:475-483.

4. De Avila, A. C., de Hann, P., Kormelink, R., Resende, R. de O., Goldbach, R., and Peters, D. 1993. Classification of tospovirus based on phylogeny of nucleoprotein gene sequences. J. Gen. Virol. 74:153-159.

5. De Borbón, C. M., Gracia, O., and Feldman, J. M. 1995. Estudio de los vectores de virus de la peste negra del tomate (TSWV) en Argentina. Page 110 in: III Congreso Argentino de Entomología, Mendoza, Argentina.

6. Dewey, R. A., Semorile, L. C., and Grau, O.

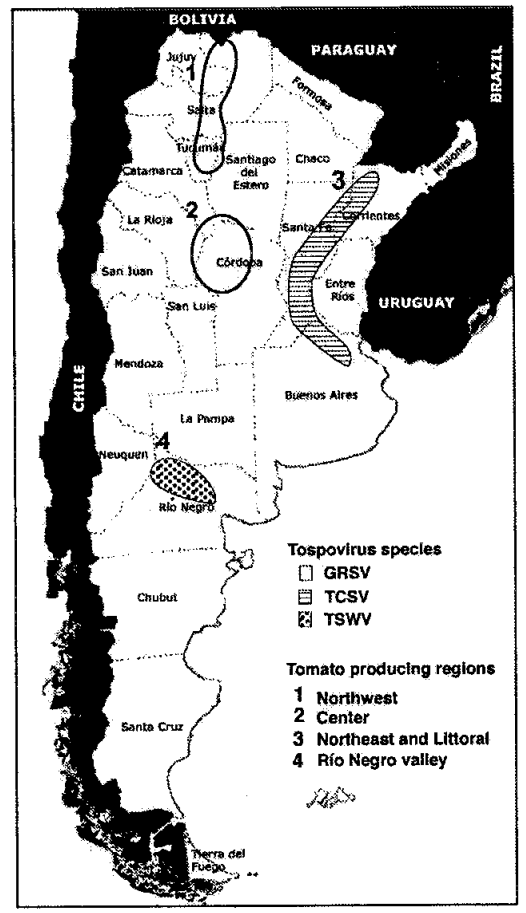

Fig. 2. Geographical distribution of Groundnut ringspot virus (GRSV), Tomato chlorotic spot virus (TCSV), and Tomato spotted wilt virus (TSWV) in the main tomato-producing regions of Argentina.

1996. Detection of Tospovirus species by RTPCR of the N-gene and restriction enzyme digestions of the products. J. Virol. Methods 56:19-26.

7. Fawcet, G. 1938. La corcova del tabaco y su presencia en plantaciones de tomate. Pages 110 in: Circular Estación Experimental Agrícola de Tucumán. Vol. 60, Tucumán, Argentina.

8. Francki, R. I. B., Fauquet, C. M., Knudson, D. L., and Brown, F. 1991. Classification and nomenclature of viruses: Fifth report of the International Committee on Taxonomy of Viruses. Arch. Virol. Suppl. 2:1-450.

9. German, T. L., Ullman, D. E., and Moyer, J. 1992. Tospoviruses: Diagnosis, molecular biology and vector relationships. Annu. Rev. Phytopathol. 30:314-348.

10. Gracia, O., De Borbón, C. M., Granval de Millan, N., and Cuesta, G. V. 1999. Occurrence of different Tospoviruses in vegetable crops in Argentine. J. Phytopathol. 147:223227.

11. Nagata, T., Almeida, A. C. L., Resende, R. O., Franca, F. H., and De Avila, A. C. 2000. The transmission specificity and efficiency of Brazilian Tospoviruses occurring of tomato by four thrips species. Page 816 in: XXI International Congress of Entomology, Brazil.

12. Nagata, T., De Avila, C. A., Tavares, P. C. T., Barbosa, C. de J., Juliatti, F. C., and Kitajima, E. W. 1995. Occurrence of different Tospoviruses in six states of Brazil. Fitopatol. Bras. 20:90-95.

13. Power, A. G. 2000. Insect transmission of plant viruses: A constraint on virus variability. Curr. Opin. Plant Biol. 3:336-340.

14. Pozzer, L., Bezerra, I. C., Kormelink, R., Prins, M., Peters, D., Resende, R. de O., and De Avila, A. C. 1999. Characterization of a tospovirus isolate of iris yellow spot virus associated with a disease in onion fields in Brazil. Plant Dis. 83:345-350. 